University of Nebraska - Lincoln

DigitalCommons@University of Nebraska - Lincoln

Publications from USDA-ARS / UNL Faculty

U.S. Department of Agriculture: Agricultural

Research Service, Lincoln, Nebraska

2013

Current State of Weed Management in Organic and Conventional

Cropping Systems

Alec F. McErlich

Earthbound Farm, Inc., amcerlich@ebfarm.com

R. A. Boydston

USDA-ARS, rick.boydston@ars.usda.gov

Follow this and additional works at: https://digitalcommons.unl.edu/usdaarsfacpub

McErlich, Alec F. and Boydston, R. A., "Current State of Weed Management in Organic and Conventional Cropping Systems" (2013). Publications from USDA-ARS / UNL Faculty. 1387.

https://digitalcommons.unl.edu/usdaarsfacpub/1387

This Article is brought to you for free and open access by the U.S. Department of Agriculture: Agricultural Research Service, Lincoln, Nebraska at DigitalCommons@University of Nebraska - Lincoln. It has been accepted for inclusion in Publications from USDA-ARS / UNL Faculty by an authorized administrator of DigitalCommons@University of Nebraska - Lincoln. 


\title{
Chapter 2 \\ Current State of Weed Management in Organic and Conventional Cropping Systems
}

\author{
Alec F. McErlich and Rick A. Boydston
}

\begin{abstract}
Crop losses due to weeds result in reduced yields and quality and increases in harvest costs. Weed management often requires major resource inputs to produce a successful crop. Herbicides are central to the conventional approach to weed management, and they have allowed the grower to reduce management priority, time, effort, and cost of managing weeds. Their use has at times come at a price such as herbicide-resistant weeds, environmental damage, reduced water quality, and loss of genetic diversity. Although growers use a combination of management practices to control weeds, differences between those used in conventional agriculture compared to organic production systems often vary widely in their implementation and relative importance. Approaches to weed management within an organic system revolve around implementing a range of techniques, often consecutively over the course of the cropping rotation. For both organic and conventional growers, weed management remains a significant impediment to optimizing crop yield, improving crop quality, and reducing the costs of production.
\end{abstract}

\section{Introduction}

Weeds are ubiquitous to most crops. Most agricultural soils contain millions of weed seed per hectare, and if left unmanaged, weeds greatly reduce crop yields by competing with the crop for nutrients, light, and water. Unlike most other agricultural

\footnotetext{
A.F. McErlich ( $\square)$

Earthbound Farm, Inc., San Juan Bautista, CA 95045, USA

e-mail: amcerlich@ebfarm.com

R.A. Boydston

US Department of Agriculture, 24106 N. Bunn Road, Prosser, WA 99350, USA

e-mail: rick.boydston@ars.usda.gov
} 
pests, weeds are present every year in every field and require some degree of management for optimum crop yields and profitability. Weeds comprise the first stage of plant succession following soil disturbance and removal of native vegetation. From the time man first started manipulating crop plants to grow in designated areas rather than gathering food from nature, controlling competing vegetation became a primary task. Planting crops in rows facilitated cultivation and weeding options. Row spacing was largely based on the width of the particular animal or machine that would be used to cultivate the crop.

Crop losses due to weeds vary by crop, weed species, location, and farming system (Bridges 1992; Swinton et al. 1994). Weeds can directly reduce crop yields, reduce crop quality, and increase harvest costs. Weeds not only compete for nutrients, light, and water but can also harbor pests (nematodes, insects, pathogens) of the crop reducing potential yields and quality further (Boydston et al. 2008). Weeds can also reduce the value of the harvested crop such as lowering protein levels in grain and decreasing fruit or seed size. The presence of weeds in the harvested crop may also lower the value of the crop. Jointed goat grass (Aegilops cylindrica) in wheat (Triticum aestivum) seed, puncture vine (Tribulus terrestris) burs and nightshade (Solanum sp.) berries in green peas (Pisum sativum), nightshade stains on beans (Phaseolus vulgaris), and horseweed (Conyza canadensis) oil distilled with peppermint (Mentha piperita) oil are examples of weeds contaminating and lowering the value of the harvested crop. A Canadian survey of crop losses due to weeds in 58 commodities reported average annual losses of $\$ 984$ million due to weeds (Swanton et al. 1993). Lentil (Lens culinaris) and cranberry (Oxycoccus sp.) crops had the greatest percent yield loss due to weeds $(25 \%)$, whereas the major crops of corn (Zea mays), soybean (Glycine max), hay, wheat, potato (Solanum tuberosum), canola (Brassica napus), and barley (Hordeum vulgare) had the greatest monetary value losses.

Most fields are infested with multiple weed species which interact resulting in a combined effect on the crop. Crops vary in their ability to compete and tolerate weeds. Soybean yield was reduced more by weeds than corn yields in previous studies (Swinton et al. 1994). Onions (Allium cepa) lack a competitive crop canopy to shade weeds and are susceptible to nearly total crop loss due to uncontrolled weeds (Williams et al. 2007).

\section{Changing Consumer Attitude Toward Food}

The publication of Rachel Carson's book Silent Spring in 1962 is seen by many as the beginning of the modern organic era in the USA. It undoubtedly created a consciousness of environmental issues and food production practices of the time. An increasing consumer awareness of production practices, pesticide residues, food safety, human health, animal welfare, and food quality is largely 


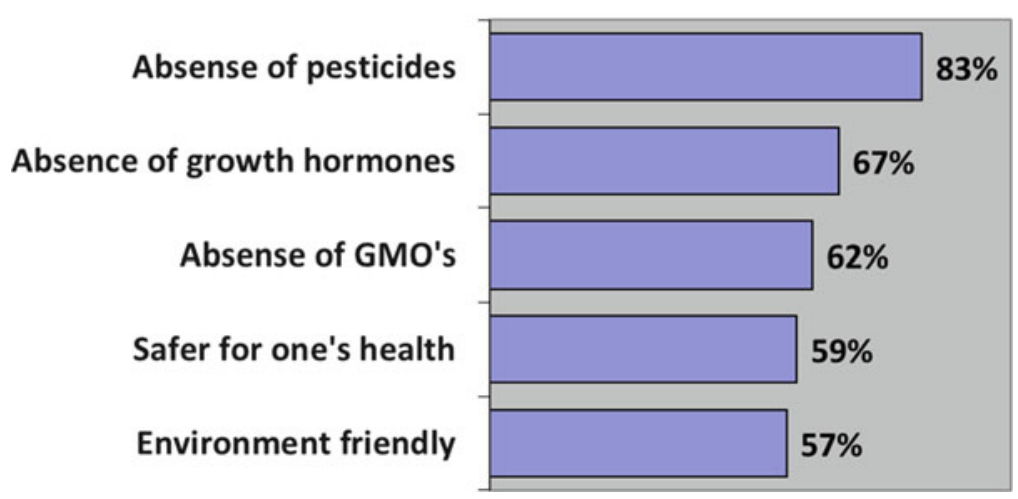

Fig. 2.1 Top five US consumer properties associated with "organic" (Abbrev. from Hartman 2007)

responsible for the increased demand for organic foods (Fig. 2.1). A recent survey of US consumers revealed that nearly two-thirds believe foods are less safe due to chemical use during production and processing (Anon 2010). An increasing number of consumers associate healthy food consumption with improved personal health and wellness. Food is seen as a first step to treating and preventing health problems (Hartman 2010).

Global consumer demand for organic foods continues to increase particularly in Western markets. The higher price of organic foods is often cited as a major reason why consumers avoid buying organic products (Stolz et al. 2011; Sadek and Oktarani 2009). This has led some consumers to seek not only organic foods, but also items labeled as locally sourced, eco-friendly, third party audited, socially responsible, and products produced within sustainable production and processing systems, a trend now termed by many as "beyond organic." Many food and supermarket companies have established production guidelines or require third-party audits of suppliers as part of standard procurement contracts. Third-party verification of production practices is often used to show consumers that a product is produced to set standards by affixing the audit organization logo to the product packaging. Independent third-party verification of production systems is an increasingly common practice within the food industry and has led to an upsurge in the number of various eco-labels worldwide. Examples from the USA are shown in Fig. 2.2. Food and agriculture companies have expanded their corporate social responsibility (CSR) reporting to include not just financial and regulatory information but also measures taken to address sustainable growth, environmental impact, equitable employment policies, and social issues (Martinez 2007). 


\begin{tabular}{|c|c|c|c|c|c|}
\hline Organic & $\begin{array}{l}\text { Reduced } \\
\text { Pesticides }\end{array}$ & $\begin{array}{l}\text { Socially } \\
\text { Responsible }\end{array}$ & Eco Friendly & Sustainable & $\begin{array}{l}\text { Animal } \\
\text { Welfare }\end{array}$ \\
\hline USDA & NutriClean & $\begin{array}{l}\text { Fair Trade } \\
\text { Certified }\end{array}$ & $\begin{array}{l}\text { RainForest } \\
\text { Alliance }\end{array}$ & Food Alliance & $\begin{array}{l}\text { Certified } \\
\text { Humane }\end{array}$ \\
\hline $\begin{array}{l}\text { Canada } \\
\text { Organic }\end{array}$ & $\begin{array}{l}\text { Protected } \\
\text { Harvest }\end{array}$ & ProTerra & Salmon Safe & $\begin{array}{l}\text { Non GMO } \\
\text { Project }\end{array}$ & $\begin{array}{l}\text { Animal } \\
\text { Welfare }\end{array}$ \\
\hline Demeter & $\begin{array}{l}\text { Certified } \\
\text { Naturally } \\
\text { Grown }\end{array}$ & $\begin{array}{l}\text { Certified } \\
\text { Fair } \\
\text { Labor }\end{array}$ & $\begin{array}{l}\text { Approved } \\
\text { Dolphin Safe }\end{array}$ & LIVE & $\begin{array}{l}\text { American } \\
\text { Grassfed }\end{array}$ \\
\hline BioGro & & & Bird Friendly & & \\
\hline
\end{tabular}

Fig. 2.2 Examples of third party food certification labels found in US markets

\section{Organic Agriculture}

The organic principles involve recognition of the values diversity and natural systems bring to the relationships associated with our use of the planet's resources, crops, and animals to produce food, fiber, and materials. The International Federation of Organic Agricultural Movements (IFOAM) expresses these principles under four core headings of Health, Ecology, Care, and Fairness.

The four principles of organic agriculture as defined by IFOAM (IFOAM 2005) are

- Health —organic agriculture should sustain and enhance the health of soil, plant, human, and planet as one and indivisible.

- Ecology —organic agriculture should be based on living ecological systems and cycles, work with them, emulate them, and help sustain them.

- Fairness - organic agriculture should build on relationships that ensure fairness with regard to the common environment and life opportunities.

- Care-organic agriculture should be managed in a precautionary and responsible manner to protect the health and well-being of current and future generations and the environment.

\subsection{Definitions}

The International Federation of Organic Agricultural Movements (IFOAM) defines organic agriculture as "a production system that sustains the health of soils, 
ecosystems and people. It relies on ecological processes, biodiversity and cycles adapted to local conditions, rather than the use of inputs with diverse effects. Organic agriculture combines tradition, innovation, and science to benefit the shared environment and promote fair relationships and good quality of life for all involved."

The early history of organic movement is provided by Conford (2001) and Kristiansen and Merfield (2006). Standards defining the methods by which organic producers operated were first developed in Europe in the 1940s. By the 1970s certification using third-party agencies began to occur, replacing the internal audit systems used by the earliest standards organizations. Today public and private thirdparty certifiers play a key role to ensure standards are adhered to in all aspects of production through to the customer. Legal definitions and regulations in many counties ensure organic label claims are substantiated by third-party audit programs. A number of countries, including the European Union, USA, Japan, and Canada, have defined "organic" within law and only certified operations may use this term. Seventy-six countries now have some form of organic regulation in statute (Huber 2011). While standards worldwide may differ to some degree, largely in response to local needs and practices, ongoing efforts are underway to establish equivalency agreements in order to harmonize certification and facilitate international trade. As part of the 1990 Farm Bill the US Congress passed the Organic Foods Production Act (OFPA) to enable establishment of the US National Organic Standards. These standards went into effect in April 2001 and are regulated and enforced by the National Organic Program (NOP) of the Agricultural Marketing Service, US Department of Agriculture (USDA).

\subsection{World Production}

As consumer demand for organic products has increased, so has the land area under organic production. Increasing distribution via mainstream retailers has also driven market growth. Demand from the larger organic market countries of North America, Asia, and Europe has led to an increasing international export trade from African and Latin American countries. Demand for warmer climate crops such as coffee, and the need for counter season supply, has allowed an increasing number of producers in these countries to supply export markets. The rapid consumer demand for organic products in the USA caused periodic product shortages due to supply limitations (Dimitri and Oberholtzer 2009) and as a result led to an increased need for imported products.

The world total area under organic production (agricultural and nonagricultural [beekeeping, wild harvest, forestry, aquaculture, grazed nonagricultural land] production areas combined) reached 80 million hectares in 2010 (Willer and Kilcher 2012). The land area under organic agricultural production increased by $22 \%$ in the 5-year period from 2005 to 2009 and had reached 37.2 million hectares in 2009 (Willer and Kilcher 2011). By 2009, the worldwide number of organic producers totaled 1.8 million, a 400,000 increase from the previous year (IFOAM 2010). 
Table 2.1 A world view: regional organic agricultural land area and number of producers 2010 (Willer and Kilcher 2012)

\begin{tabular}{lccc}
\hline & $\begin{array}{c}\text { Agricultural land } \\
\text { area (ha, mil) }\end{array}$ & $\begin{array}{l}\text { World organic } \\
\text { agricultural area (\%) }\end{array}$ & $\begin{array}{l}\text { Number of } \\
\text { producers }\end{array}$ \\
\hline Africa & 1.1 & 3.0 & 540,000 \\
Asia & 2.8 & 7.0 & 500,000 \\
Europe & 10.0 & 27.0 & 280,000 \\
Latin America & 8.4 & 23.0 & 270,000 \\
North America & 2.7 & 7.0 & $17,069^{\mathrm{a}}$ \\
Oceania & 12.1 & 33.0 & 8,500 \\
\hline${ }^{a}$ 2009 & & &
\end{tabular}

From 2006 to 2010 the global organic food market grew at a compound annual growth rate of $12 \%$, to reach $\$ 59.3$ bn. USD in 2010 (Datamonitor 2011). In comparison total world food products were valued at US\$4.2 trillion in 2009, representing a $3.7 \%$ compound annual growth rate for the period 2005-2009 (Datamonitor 2011). Sales of organic foods at the retail level have grown by $20-35 \%$ in many countries with a well-developed organic market (Thompson 2000). In 2009 the USA represented the largest organic market ( $\$ 25.5$ bn. USD), followed by Germany ( $\$ 8.3$ bn. USD) and France ( $\$ 4.3$ bn. USD) (IFOAM 2010). Of the total world food market, organic sales are less than $3 \%$ (Thompson 2000) (Table 2.1).

\subsection{World Land Use and Crops}

Of the 37.2 million hectares under organic management in $2009,47 \%$ was classified as agricultural lands, i.e., cropland, permanent grassland, and other agricultural land. The remaining $53 \%$ was utilized for forestry, beekeeping, aquaculture, and grazing on nonagricultural land (Willer and Kilcher 2011). In 2009, $0.9 \%$ of the world's agricultural land was managed using organic practices.

The major arable crops in organic agriculture are cereals (including rice), green fodder, oilseeds, vegetables, and protein crops. The area in cereals is underreported as producer countries such as India, China, and the Russian Federation did not report data (Willer and Kilcher 2011). The major permanent crops are coffee, olives, cocoa, nuts, and grapes (Willer and Kilcher 2011). The total arable land in organic production accounts for $0.4 \%$ of the world's total arable land area.

\subsection{Weed Management}

Although some see organic agriculture as returning to the techniques of an earlier era, it is in practice a combination of traditional methods along with modern innovation and science. Organic agriculture is a set of management practices that rely on 
integrating natural cycles, enhanced biodiversity, preservation of natural resources, and improved soil health and quality, in order to promote ecological balance. It is a system that provides a range of ecosystem services such as improved soil tilth, lower energy use (Reganold et al. 2001; Refsgaard et al. 1998; Gündoğmus 2006; Mäder et al. 2002), reduced pesticides (Mäder et al. 2002), greater biodiversity (Mäder et al. 2002; Letourneau and Bothwell 2008), and increased carbon sequestration (Pimentel et al. 2005).

Weed control methods are broadly categorized as mechanical, biological, cultural, chemical, and preventative. Although most farmers may use a combination of management practices to control weeds, the approaches and priority ranking placed against each practice used in conventional and organic agriculture are often very different. Weed management in organic systems revolves around implementing a range of techniques within an integrated natural-based system, rather than reliance on a single or narrow selection of management techniques, typical of industrial agriculture. Some describe this as the "many hammers" approach as several actions are taken, often consecutively, over the course of the cropping rotation to reduce the weed burden. Within conventional agriculture the overwhelming reliance is on the use of herbicides to largely eliminate weed competition. While management practices, such as the use of crop rotation and cover crops, are widely used by mainstream agriculture, their primary functions are not directed toward weed management. Organic growers on the other hand recognize these practices as a core function of a good weed management program.

Of all the production challenges facing organic growers, weed management remains for most one of the most difficult, frustrating, expensive, and timeconsuming management aspects of producing a crop for market. Despite an increasing selection of cultivation equipment and an improved understanding of weed management techniques and weed ecology, growers continue to find weed management a significant impediment to optimizing yield, quality, and income. Grower concerns over an inability to control weeds are often cited as the leading deterrent to converting to organic production. Numerous grower surveys of organic agriculture demonstrate that weed control remains a major and enduring challenge (Walz 1999; Kristiansen et al. 2001; Birzer and Badgery 2006; Anon 2007). This is not to say that all organic growers struggle with controlling weeds. Those growers who have implemented successful management techniques have done so through hard work, a sharp learning curve, innovation, and a firm decision not to allow weeds to develop mature seed. With time, skill, and effort, growers are able to reduce the weed seed bank to very low levels, which has resulted in significant financial benefit.

For many organic growers weed management remains one of the most resourceintensive management activities from the perspective of time, effort, input costs, potential impact on crop yield and quality, capital investment, and energy consumption. There are few times of the year when a grower is not actively working on some aspect of weed management.

Although only the US Department of Agriculture, National Organic Program (USDA-NOP) standards relating to weed management are shown, most organic 
Table 2.2 USDA-NOP standard section addressing weed management from $\$ 205.206$ crop pest, weed, and disease management practice standard

\begin{tabular}{ll}
\hline Category & Options \\
\hline Management practice & Crop rotation \\
& Soil and crop nutrient management \\
& Cultural choices (e.g., resistant to prevalent pests) \\
Pest problem (weeds) & Mulching with biodegradable materials \\
& Mowing \\
& Livestock grazing \\
& Hand weeding and mechanical cultivation \\
& Flame, heat, or electrical means \\
& Plastic or other synthetic mulch (removed at end of \\
season) \\
Biological or botanical substance (after other options)
\end{tabular}

standards in use around the world employ a similar code of practice in relation to weed management. The relevant section of the USDA-NOP standards relating to weeds (see Table 2.2) directs producers to use cultural and physical tools before utilizing any approved pesticides.

\subsection{Herbicides Accepted for Weed Management in Organic Agriculture}

An increasing number of herbicides are permitted for use in organic agriculture. These materials are based on naturally occurring compounds such as plant oils, corn gluten meal, fatty acids, acetic acid, and biological materials. Most products are categorized as plant oil extracts and act as a nonselective contact on green vegetation. Corn gluten meal acts to limit the normal development of plant roots. An acetic-acid-based product is approved for use in the USA. Soaps are used to control moss and algae. Because of the high cost of these materials, their use is limited to directed or spot sprays in higher-value crops. High spray volumes must be used to ensure adequate coverage of the target weeds. Lanini (2010) describes some characteristics of plant oil-based herbicides:

- Generally regarded as minimum risk pesticides

- Act only on small, newly emerged weeds

- Have greater efficacy against broadleaf weeds than grasses

- Require good coverage and repeat applications to achieve adequate control

- Require higher spray volumes at lower concentrations to achieve adequate control

- Lack residual action

- Require an approved adjuvant to improve efficacy

- Provide a greater level of weed control when applications occur at warm temperatures 


\section{Conventional Cropping Systems}

Throughout history, the approach to agricultural weed management has largely been influenced by the energy source for those activities. The progression from human to animal to mechanical to chemical has been influenced by the technologies of the period. In modern agricultural systems, the energy source is largely obtained from fossil fuels. Modern, industrialized approaches to agricultural production rely on high input systems, centered on the use of fossil-fuel-based inputs such as fertilizer and pesticides, to produce high yields. Improvements in plant breeding and irrigation practices have also contributed to dramatic yield increases over several decades. There is an increasing realization that this approach has come at a price. Overuse and inappropriate use of fertilizers and agrochemicals are associated with loss of genetic diversity, reduced soil and water quality, and are linked with human health problems. Central to weed management within conventional agriculture is the use of herbicides. Herbicides often allow the producer to reduce the management priority, time, effort, and cost of managing weeds.

\subsection{Weed Management}

In conventional cropping systems, weeds are viewed as a pest that must be managed if maximum yields and profits are to be realized. Due to the high level of weed control obtained with synthetic herbicides, grower's expectations and goals of weedfree fields have become the norm, sometimes without warrant with regard to the level of weed control required to eliminate negative effects on crop yield. As in organic systems, weed management in conventional cropping systems relies on a combination of cultural, mechanical, chemical, and biological methods, but because of the great degree of efficacy and selectivity of modern synthetic herbicides and the simplicity of their use, conventional agriculture relies heavily on chemical weed control methods. Prior to the 1950s most weed control in cropping systems was accomplished with a combination of mechanical cultivation tools, hand weeding, and cultural practices. Weed control was a major task for producers requiring a major portion of their time in the field. As synthetic herbicides became available, growers discovered they could control most weeds in a fraction of the time and with a much higher level of control than with cultivation. In- row weed control, often difficult and expensive with mechanical means, became easily accomplished with synthetic selective herbicides. Crafts (1960) and Timmons (1970) provided detailed histories of the twentieth-century weed control developments in the USA and Canada. Following the discovery of 2,4-D in the early 1940s, the number of herbicides used or tested in the USA and Canada increased from 15 to 120 in 1969 (Timmons 1970).

Modern conventional agriculture relies heavily on synthetic herbicides to manage weeds due to the relatively low cost, ease of use, and high efficacy. 


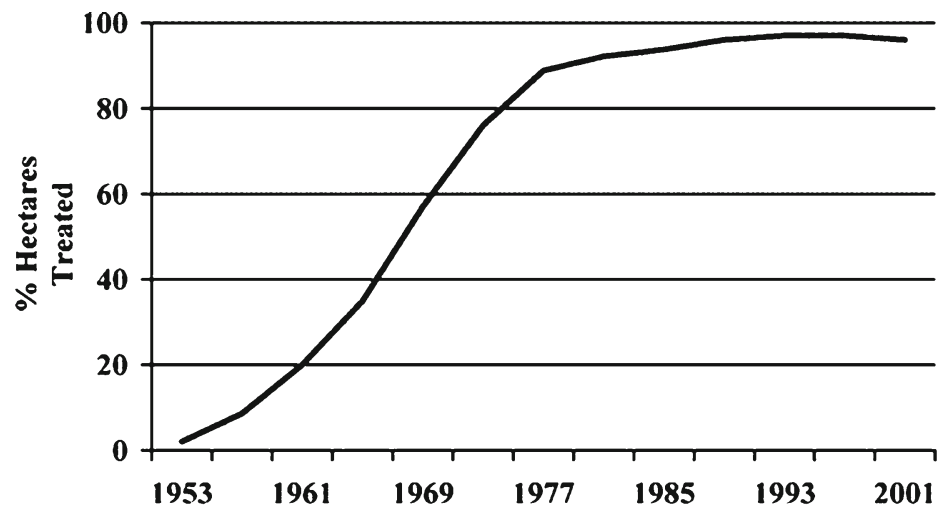

Fig. 2.3 Land area treated with herbicides in six major U.S. crops (Gianessi and Reigner 2007) (Note: Trendline of corn, cotton, soybean, sugarbeet, peanut, and rice. Source: Brodell et al. 1955; Strickler and Hindson 1962; USDA 1968, 2001; Eichers 1978; Duffy 1983; Andrilenas 1975)

Herbicides account for approximately two-thirds of expenditures for all pesticides used in US agriculture (Gianessi and Reigner 2007). The herbicide 2,4-dichlorophenoxyacetic acid (2,4-D) was the first widely used synthetic herbicide in modern agriculture (Timmons 1970). It was first commercialized in the late 1940s and was rapidly adapted by producers of corn, wheat, rice (Oryza sativa), and other grass crops for broad-spectrum broadleaf weed control. 2,4-D was relatively inexpensive, easy to apply, and controlled many problem broadleaf weeds that were often difficult to manage with cultivation and other methods. Perennial weeds, such as Canada thistle and field bindweed, were particularly difficult to control before the advent of 2,4-D, requiring repeated cultivation and often sacrificing an entire growing season without a crop to reduce the weed pressure with repeated tillage (Freed 1980).

The 1950s saw the introduction of the triazine family of herbicides, including atrazine and simazine. Atrazine and simazine were widely used in crops such as corn and fruit trees for preemergence weed control. These herbicides were persistent in the soil and provided control of most annual weeds for several months. Despite the weed control benefits of atrazine, its relatively high mobility in the soil coupled with its long persistence and extensive use led to atrazine contamination of groundwater in many production areas. In addition, repeated use of atrazine eventually led to selection of herbicide-resistant weed biotypes (Bandeen et al. 1979; Heap 2011).

Increases in herbicide use led to increases in pesticide use in agriculture for many years. As a percentage of total pesticides applied, herbicides rose from $33 \%$ in 1966 to $70 \%$ in 1986, and herbicides still dominate in terms of kilograms of active ingredients applied. Land area treated with herbicides in six major crops tripled from the early 1960s to the early 1970s as farm size increased and pesticide companies developed many new selective herbicides Fig. 2.3. Over $90 \%$ of (the six major crops corn, cotton, soybean, sugar beet (Beta vulgaris), peanut (Arachis hypogaea) and rice) are treated with herbicides (Gianessi and Reigner 2007), 
Table 2.3 World and US pesticide amount by pesticide type—2007 (Grube et al. 2011)

\begin{tabular}{lccccr}
\hline & \multicolumn{2}{l}{ World market } & & & US market \\
\cline { 2 - 3 } Type & Mil kg a.i. & $\%$ & & Mil kg a.i. & $\%$ \\
\hline Herbicides $^{\mathrm{a}}$ & 951 & 40 & & 241 & 47 \\
Insecticides $^{\text {Fungicides }}$ & 405 & 17 & & 42 & 8 \\
Others $^{\mathrm{b}}$ & 235 & 10 & & 32 & 6 \\
Total & 773 & 33 & & 199 & 39 \\
\hline
\end{tabular}

${ }^{a}$ Herbicides include herbicides and plant growth regulators

${ }^{\mathrm{b}}$ Others include nematicides, fumigants, and other miscellaneous conventional pesticides, and other chemicals used as pesticides such as sulfur, petroleum oil, and sulfuric acid

and corn and soybean production accounts for the majority of US herbicide use (Vecchia et al. 2009).

Glyphosate was introduced in 1974 for nonselective weed control. Glyphosate allowed growers to control weeds without preplant tillage and was crucial for the adoption of reduced conservation tillage systems. Most growers of the major row crops have adopted reduced or no-till production practices that reduce soil erosion and help maintain soil organic matter and rely on contact or burn down type herbicides, such as paraquat and glyphosate. Glyphosate is now the major herbicide used in selective weed control due to the development of crop plants that are resistant to it. Although less soil erosion occurs in no-till or reduced till systems, increased use of herbicides is also common, which can lead to selection for herbicide-resistant weeds.

The amount of pesticide used in the USA accounted for $23 \%$ of total world pesticide amount used and $25 \%$ of world herbicide amount used (Grube et al. 2011). Herbicides still account for the largest portion of the USA and world pesticide use (Table 2.3). Herbicides used in the USA in 2007 exceeded 240 million $\mathrm{kg}$ and accounted for $47 \%$ of the total pesticide use (Table 2.3). In part due to the widespread use of herbicides and excellent efficacy, herbicide research has dominated the discipline of Weed Science for several decades (Zimdahl 2000).

Herbicides have brought numerous benefits to farmers including high efficacy, reduced trips through the field, ease of use, lower labor and cultivation costs, less time spent on weed control, and reduced soil erosion. Despite the numerous benefits of herbicides, there are undesirable effects associated with herbicide use including environmental and health issues. Herbicide-resistant weeds, misapplication, off-target movement, and persistence of some herbicides in soil can injure susceptible crops. Environmental concerns including herbicide contamination of ground and surface waters have led to attempts to reduce herbicide inputs in agriculture. Alternative weed management practices (cultivation, crop rotation, cover crops, mowing, mulching, etc.) are typically used in combination with herbicides in most production systems. Banding of herbicides in the crop row combined with cultivation between the rows rather than broadcast spraying is sometimes used to reduce herbicide inputs. 
New sprayer technology is available that only applies herbicide when a weed is identified, but has had limited adoption by growers to date. One example of this technology is the WeedSeeker@ sprayer which utilizes optics and computer circuitry to detect green plants and activate spray nozzles to apply a nonselective herbicide. Sprayers equipped with this technology are able to reduce the total amount of herbicide applied when weed canopies do not entirely cover the ground and have been utilized primarily for controlling weeds in fallow ground.

The heavy reliance of conventional agriculture on synthetic herbicides has decreased grower knowledge and use of alternative weed control practices (mechanical and cultural) that are standards in organic production. Quite often when new weed problems emerge, the mind-set of conventional grower is to look for the next best herbicide treatment rather than to evaluate the possible causes of the problem and adjust cultural or other weed management practices accordingly.

New weed management options are needed to prevent and delay development of herbicide-resistant weeds. Simply rotating herbicide mode of action is often effective, but not in all cases, and multiple resistance to herbicides with different modes of action has developed in numerous weed species. Growers must adopt and develop other technologies for weed control that compliment and extend the utility of the herbicide tools they now have. Continuous, repeated, and exclusive selection pressure on weeds from any weed control tactic will select for weeds resistant or tolerant to the specific control tactic. Weed community shifts can occur as a result of natural tolerance to the herbicide used or through an avoidance strategy related to weed emergence timing. An integrated approach to weed management is required to prevent or retard the development of resistant weed populations. Use of diverse crop rotations and cultural practices that suppress weeds and mechanical, biological, and chemical control methods all contribute to slowing or preventing the development of resistant weeds. New technologies such as robotic weeders could be used to compliment current weed control methods by eliminating seed production of escape weeds and providing new selection pressure unrelated to that of herbicides.

\subsection{Herbicide-Resistant Crops}

Major acreage crops such as field corn, soybeans, wheat, and cotton drive most of the development of new herbicides as the high development, registration, and regulatory costs can be more readily recuperated with the large sales volume. More recently, seed companies have developed herbicide-resistant traits for many of the major acreage crops. Grower adoption of genetically modified crops with resistance to glyphosate has occurred rapidly in corn, soybeans, cotton, canola, sugar beets, and alfalfa (Medicago sativa). The broad spectrum of weed control, low cost, ease of use, and reduction in cultivation when using this technology has resulted in the most rapidly adopted technology in the history of agriculture (Dill et al. 2008). 


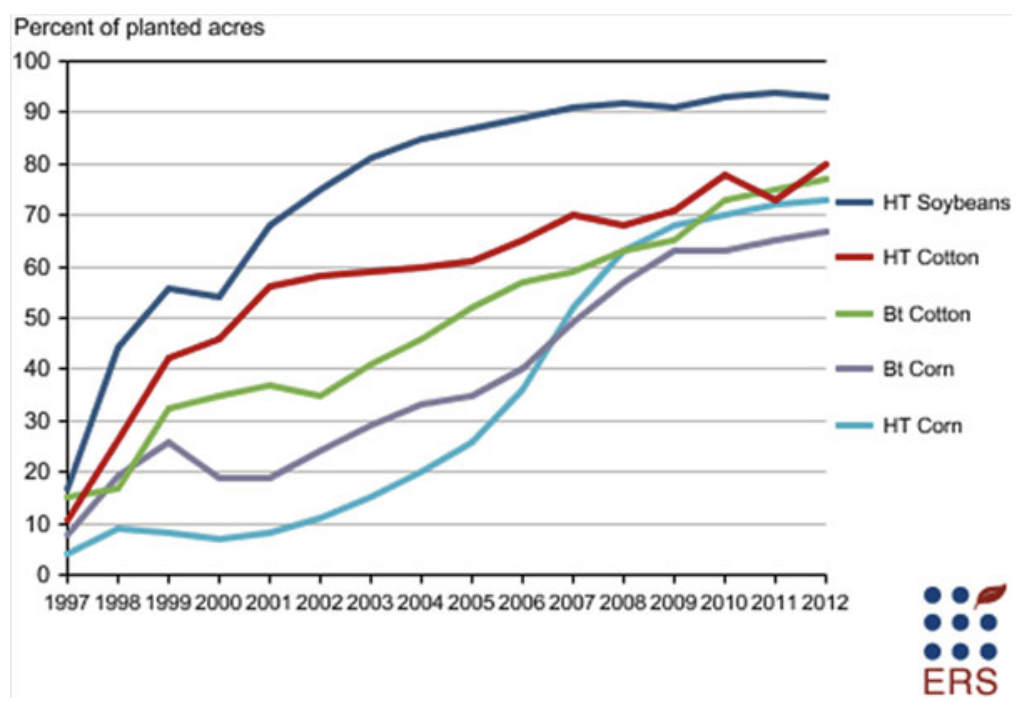

Fig. 2.4 Adoption of genetically engineered crops in the US (USDA ERS 2011) (Data for each crop category include varieties with both HT and Bt (stacked) traits. Source: USDA, Economic Research Service)

In some cases, the herbicides used in herbicide-resistant crops are more convenient to use, less toxic to mammals, and less persistent in the environment (Cerdeira and Duke 2006). Initially, glyphosate was extremely effective in controlling weeds in glyphosate-resistant crops, and many growers relied exclusively on glyphosate to manage weeds. Due to the intense selection pressure placed on weed populations with the widespread use of glyphosate, weed resistance to glyphosate has become more prevalent. Weed management programs cannot rely on single tactics, whether an herbicide or other form of weed control, or weeds will ultimately adapt and survive in large numbers. Weed resistance to glyphosate has forced many growers to rotate to or tank mix with herbicides having a different mode of action. Combining herbicides, cultural practices, and mechanical tactics provides the greatest protection from herbicide-resistant weeds and is part of an integrated weed management program.

Most high-value fruit and vegetable crops are grown on fewer hectares and have not had the luxury of new herbicide development due to the lower market potential and higher risk of crop injury. As a result, herbicide development for these crops usually consists of adapting and registering herbicides that were developed for one of the major field crops. This often results in fewer and older herbicides labeled on these higher-value crops and sometimes no herbicides available for control of certain problem weeds. Consumers have also voiced concern about the safety of genetically modified crops to humans and the environment. This, coupled with the lower profit incentive due to lower acreage, few seed companies have developed herbicide-resistant fruit and vegetable crops. As a result, many specialty fruit and vegetable growers rely more heavily on tillage, cultivation, mulching, and hand weeding to manage weeds (Fig. 2.4). 
Risks associated with herbicide-resistant crops include marketing problems with grain contamination, segregation and introgression of herbicide-resistant traits, marketplace acceptance, and an increased reliance on herbicides for weed control. The evolution of glyphosate-resistant Palmer amaranth (Amaranthus palmeri), common water hemp (Amaranthus tuberculatus), creeping bent grass (Agrostis stolonifera), horseweed (Conyza canadensis), rigid ryegrass (Lolium rigidum), and goose grass (Eleusine indica) is directly attributable to the adoption of glyphosateresistant crops and the concomitant use of glyphosate as the primary herbicide for weed management (Green and Owen 2011; Owen and Zelaya 2005).

\section{Weed Management Challenges in Organic and Conventional Systems}

The rate of conversion to organic production in the USA has not kept pace with consumer demand, despite significant price premiums for many organic crops. Grower concerns about converting to organic agriculture are in part associated with the steep learning curve needed to acquire new knowledge and expertise, lower potential yields during the initial years, a lack of an organic price premium during the transition years, and the need to acquire an understanding of the functionality of the markets and companies involved in moving crops into the consumer market. Growers are concerned for the economic risks associated with converting their farm to an organic system (McCann et al. 1997). It may take several years before crop performance reaches parity with pre-conversion yields.

While conventional growers place considerable emphasis on herbicides to manage weeds, both conventional and organic growers recognize cultivation as an important management strategy (Doohan et al. 2010). A high proportion of organic farmers often associate weed problems on their farms with a failure of good weed management practices on adjacent land while downgrading their own poor practices as the cause of the weed problem (Doohan et al. 2010). A lack of good weed identification and taxonomy skills by growers often hinders good weed management decisions. The consistent and timely implementation of a diverse range of management practices allows the organic grower to minimize the impact of weeds within a rotation and over time reduce weed control costs to a minor portion of the total costs of production (Fig. 2.5).

The availability of herbicides often provides the conventional grower an opportunity to reduce the degree of seedbed preparedness compared to that required for optimal establishment of organic crops. Consistency of soil tilth and surface evenness are core requirements to optimizing the performance of inter-row weeding implements after seeding. Growers often require time to learn the finer aspects of seedbed preparation in order for later weed cultivations to be performed with a high degree of accuracy and efficiency. Often excess soil volume from the between rows, deep channeling caused by seed drill press wheels, and/or clods will hinder the desired flow of soil off cultivator tines or knives. This often results in the crop being 


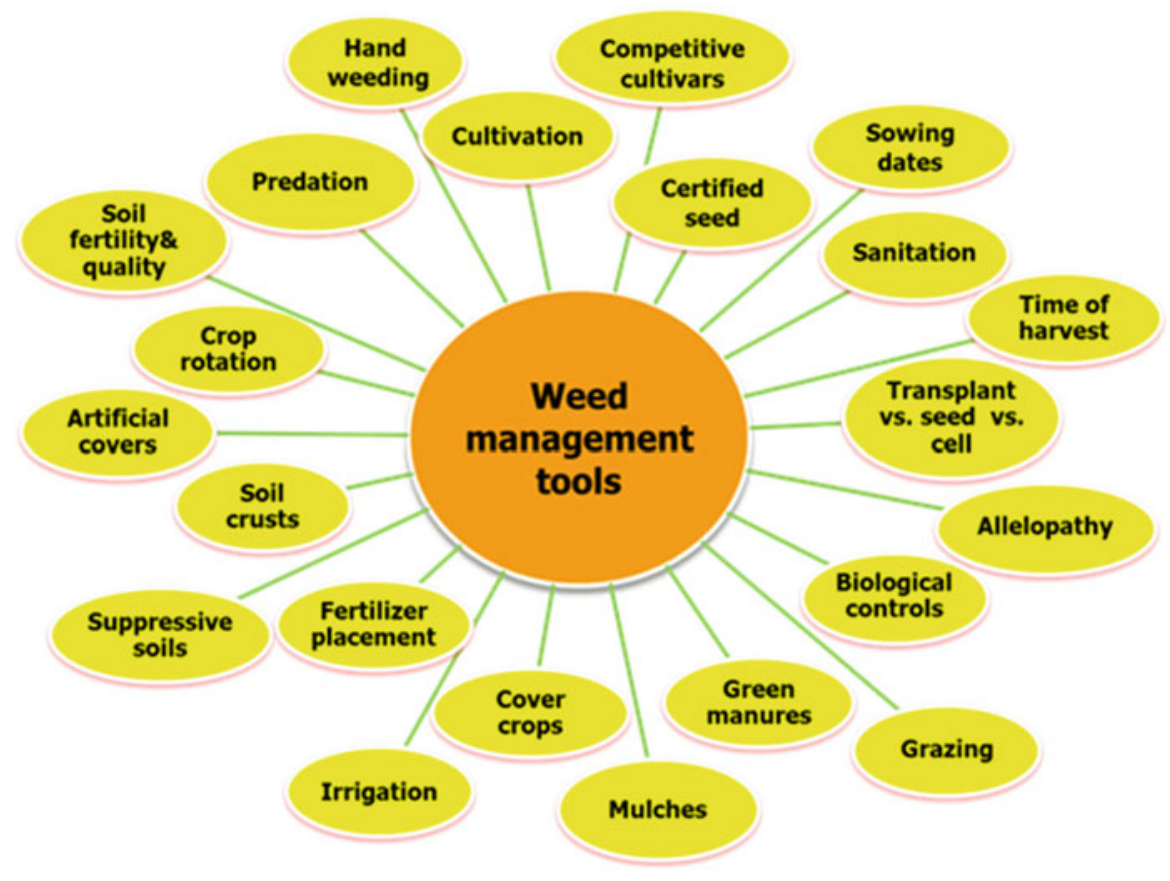

Fig. 2.5 Examples of weed management practices utilized by organic growers

submerged by excess soil and results in plant loss or delayed plant development. Here the crop is most susceptible to loss at the earliest growth stage and the initial cultivation following seeding.

\subsection{Hand Weeding}

The term hand weeding applies to not just physically pulling weeds by hand but also the use of hand tools to manage weeds. Artifacts show hand hoes have been used for thousands of years in the cultivation of crops important to humanity. The sixth Babylonian King Hammurabi mentions them in the Code of Hammurabi around 1700 BCE. Figurines from the Tang Dynasty 600-900 CE depict farmers holding hand hoes. Today the hand hoe continues to play an important role where row crops are grown, be they in traditional cultures or industrial agriculture.

Hand weeding often remains a core means to control weeds particularly for small area organic growers, where perhaps high capital costs and lack of size-appropriate equipment negate investment in specialized cultivation equipment. This is not to say large area or high-value crop growers do not use hand labor. In large-scale systems there is a need to invest in weeding equipment in order to cover large areas, within 
short periods of time, when optimal weed control opportunities exist. For conventional onions, carrots, mint, and grass seed growers, hand weeding is still an important option to controlling weed escapes and volunteer crops (Williams and Boydston 2005). Growers will use hand labor to remove potential contaminant weeds prior to harvest or to remove immature seeds before seed is added to the soil seed bank. A typical example involves processing green peas (Pisum sativum) where Canada thistle (Cirsium arvense) flower buds are potential contaminants at harvest. In addition, hand removal of weeds that escape common herbicide programs in conventional crops is an important and effective strategy to prevent development of herbicide-resistant weed populations.

The decision to use hand labor is typically dictated by the need for botanical purity in the resulting crop. Growers producing intensive crops with stringent quality requirements will often utilize hand labor to remove potential contaminant weeds prior to harvest. This is particularly important in herb and fresh salad crops, for example, where the need for botanical purity is a critical requirement leading up to harvest and where the tolerance for extraneous vegetative matter within the crop is extremely low.

Access to a skilled labor force is an ongoing concern for most growers as costs increase and immigration requirements are intensified on foreign labor. With the need to remove weeds at an early growth stage, often at a time when the crop is also just beginning to develop, a trained hand crew can make or break a crop. Distinguishing between weed and crop at an early growth stage is frequently a challenge, and if mistakes are made they are often costly. Combined with the cost of the crew, hand weeding can often represent the most costly input to a crop.

Hand weeding is time consuming, slow, and physically demanding. In 1975 the California Supreme Court (Murray 1982) ruled to ban the use of the shorthandled hoe (el cortito, the short one) due to lower back injuries caused by the stooped working position workers endured. To ease the physical burden, mobile (e.g., Drängen) or tractor-mounted multi-row platforms on which workers lie or sit, are used by some row crop growers. New technologies that can kill or suppress weeds with the precision of human labor while reducing the associated costs and requirements are important for the sustainability of organic and conventional production systems.

\subsection{Crop Rotation}

The ability to rotate crops from one field to another over several years is a corner stone of annual cropping systems in organic and many conventional cropping systems. In a survey of growers, organic producers are more likely to mention rotation as a useful weed management tool (Doohan et al. 2010). More complex (diversified) rotations build multiple stress points against weeds. By growing crops with different management requirements, it is difficult for weeds to become 
a dominant factor within the rotation. The use of weed-suppressive crops can suppress weed growth following grain harvest by outcompeting the weeds for light, nutrient, and water resources. An example is the undersowing of cereals with red clover (Trifolium pratense). Increased crop and spatial diversity within a rotation allows the grower to alter the timing and types of agronomic operations throughout the growing season.

Increasing worldwide consumer demand for organic products has led to a commensurate increase in the land area under organic management and the number of organic farmers. A large portion of the growers are either new to farming, new to organic production, or both. The learning curve for these growers is often steep, not only involving production practices but also understanding access to the organic market and the companies involved in taking organic products into the marketplace. The challenge for growers is to implement a crop rotation based on agronomic and management requirements while also taking into consideration the marketability of the selected crops. Ability to access markets is often dictated by growing region and size of the farming and/or processing and/or the consumer base.

\subsection{Plant Breeding and Variety Selection}

Over thousands of years nature has demonstrated that adaptability is crucial to survival. Organic growers recognize the importance of diversity within agricultural systems, and this extends to the crop varieties grown. Critics often claim that yields from organic systems are too low to adequately feed a growing human and animal population compared to those obtained from conventional agriculture (Smil 2001). The majority of varieties used in organic agriculture come from conventional breeding programs, and their use is often based on traits considered valuable in an organic system. Only recently have we seen the development of breeding programs within and for organic agriculture. Murphy et al. (2007) demonstrated how soft white winter wheat (Triticum aestivum) varieties do not perform equally across organic and conventional agricultural systems. Few plant breeders have focused breeding efforts on weed-suppressive qualities or crop tolerance to weeds. Several factors associated with crop canopy development near emergence, canopy closure, and the reproductive period influence the ability of sweet corn (Zea mays) to suppress and compete with wild millet (Panicum miliaceum) (Yim et al. 2009). Murphy et al. (2008) compared historical and modern spring wheat varieties, for tolerance to mechanical cultivation, and found significant differences in weed biomass.

Breeding for faster emergence, improved seedling vigor, and tolerance to seedling establishment diseases in annual crops would ensure a more consistent plant stand that meets all of the other crop requirements. Crop planting date decisions are not always made by the grower, particularly in process vegetable production where the processing company typically dictates the crop sowing date. Early season crops such as green peas (Pisum sativum) are often sown into cool soils in the Pacific 
Northwest region of the USA, a major pea growing area, in an effort to avoid contaminant weeds such as nightshade (Solanum sp.) in later sown crops. Few organic seed treatments are effective at low temperatures soil. Growers typically increase seeding rates by $20-40 \%$ to compensate for expected plant loss due to disease and post-planting weed cultivation. Poor crop plant populations create an opportunity for weeds to fill the vacant space.

Growers often find the decision to initiate the first mechanical weeding operation a difficult one when crop emergence and early development occur over several days. With individual plants at different growth stages, growers frequently wait for the later emerging plants to reach a stage tolerant of mechanical weeding. Because these plants tend to be less vigorous, their initial growth rate is slow and more susceptible to damage or loss if cultivation occurs too early. Meantime weed development continues and often progresses to a growth stage beyond that for effective removal by weeding implements.

\subsection{Mechanical Cultivation}

Primary tillage is used to meet a range of objectives, including managing plant residues, weed control, warming cold soils, improving water penetration, alleviating hard pans, seedbed preparation, incorporation of fertilizer and compost, and aerating the soil. Without due care tillage can lead to soil erosion and a reduction of soil quality. Conservation practices to counter the negative factors of tillage enable soil qualities to be maintained or improved over time. Practices such as incorporating cover crops/residue, addition of compost and manures, contour tillage, and implementing sound crop rotations all have a role in conserving soils.

Limitations to mechanical cultivation include dealing with excess crop residue, weather related soil conditions, limited in row weed control, soil type, variations in crop growth, degradation of soil quality and health, operator skill, and often redistribution of weed seeds within the soil profile. Cultivation implements often require significant capital investment by the grower.

Organic growers rely on tillage as the principal method of weed control in row crop production. The types and methodology of implements used for weed management are detailed in two books: Steel in the Field, Bowman (1997), and Practical Weed Control, van der Schans and Bleeker (2006). When discussing equipment many different tactics and viewpoints are held by growers, each adapting from personal experience and situation. The introduction of organically acceptable herbicides and the recent development of roller-crimper equipment to destroy living cover crops in situ are allowing organic growers to consider the advantages of minimized tillage, strip-till and no-till systems. Utilizing precision strip tillage equipment over controlled traffic lanes may offer improved weed control in minimum tillage situations (Kurstjens 2007).

Following planting, strategies to control weeds are generally limited to mechanical and cultural methods. Between-row weed control is a relatively easy procedure in 
annual row crops grown at wide spacings, using undercutting sweeps and shovels. Cultural methods such as fast canopy closure, use of buried drip irrigation tape, and directed fertilizer applications can all assist to reduce weed growth between crop rows. The intra-row (within row) weeds are the more difficult to control particularly in crops grown at high density. Intra-row weeds also tend to reduce yields the most due to their proximity to the crop. Most hand weeding used in production fields is aimed toward these intra-row weeds. Regardless of the crop, weeds situated within the crop row are the most challenging to control particularly as crop density increases for vegetable crops such as carrots and onions. Controlling intra-row weeds and reducing hand weeding costs are primary objectives that new technologies can address for organic and conventional production practices.

Although removal of weeds is nearly always the ultimate goal, this may not always be possible when considering intra-row weeds. In some cases, the aim may be to give a competitive advantage to the crop by using transplants, preemergent flaming of weeds, plastic mulches, and stale seedbed techniques. Delaying weed development by smothering with cultivated soil may be an option in large seeded crops such as sweet corn (Zea mays) and beans (Phaseolus vulgaris). Establishing a dry soil surface mulch by careful irrigation management can reduce the number of weeds germinating from the first few centimeters of soil. During cultivation the dry soil flows off the ends of cultivator knives or tines in a free-flowing wave that, given correct forward tractor speed and equipment modification, allows the soil to move into the crop row and smoother small weeds.

Depleting the weed seed bank near the soil surface using a preplant weed flush can reduce the potential number of weeds emerging during crop establishment. Shallow cultivation or flame weeding equipment is used to minimize the movement of deeper profile, weed seed laden soils into the crop germination zone. Most growers also use this same strategy when sufficient time allows for weed germination to occur before sowing the following crop or during fallow periods.

Tillage and mowing remain the most widely utilized management tools for perennial weeds. Most techniques rely on reducing the ability of plants to produce or store food, either by removing vegetative growth or tilling the soil to expose roots and rhizomes to desiccation or freezing. In organic agriculture, perennial weed control typically involves multiyear programs employing tillage, fallow periods, competitive crops, and vegetation control and minimizing movement of reproductive material around the farm. Even with herbicides, perennial weeds often represent the most serious and difficult to control weed category for conventional and organic growers.

\section{Conclusion}

Despite a more than doubling of organic farmland in the USA between 1997 and 2005, consumer demand for organic products has at times exceeded supply for some products. Grower concern over weed management remains a major hurdle for 
existing organic growers and hinders the conversion rate of conventional land to organic production. Organic farmers face the same complex issues as conventional famers when confronted with weed management decisions, but to obtain or maintain certified organic status a more holistic approach is required. From a weed management perspective, farmers who demonstrate proficiency, are timely, understand weed ecology and biology, develop a contingency plan for every field, and have a longer-term vision for the farm are better able to manage weeds. Additional focus on improved efficiencies from farm to consumer, reduced costs of production, improved technology transfer, and enhanced yield and quality are necessary if organic producers are to meet continuing consumer demand for organic foods.

The increasing problem of herbicide-resistant weeds has contributed to a reassessment of alternative weed control methods including cultivation to ensure adequate control. Conventional growers often acquire organic production knowledge in order to overcome some of the limitations of an intensive herbicide system. Where farmers operate both conventional and organic systems, many recognize that new skills obtained from organic agriculture have application and benefits across their entire farming operation. A slowing of the rate, at which new herbicides are commercialized, input costs, and the limitations posed by a lack of label registrations on minor crops are encouraging growers to look beyond synthetic chemistry for answers to help with weed management. Uncertainty over access to adequate sources of labor to undertake weeding by hand and increasing labor rates are major issues facing growers and will necessitate new technology. Multiple weed control methods used at multiple spatiotemporal scales are necessary if we are to reduce the negative impacts of weeds on crop production. Utilizing an integrated approach by combining a greater number of existing management options will be necessary if we are to preserve agroecosystems and supply adequate food to a growing world population. New technologies offer promise to meet many of the challenges in weed control, both in organic and conventional production systems.

\section{References}

Anon (2007) Experiences and outlook of Minnesota organic farmers. Minnesota Department of Agriculture. http://www.mda.state.mn.us/news/publications/food/organicgrowing/2007orgsur vresults.pdf. Accessed 8 Nov 2012

Anon (2010) Health and wellness trends report 2010. Natural Marketing Institute, Harleysville

Bandeen et al (1979) Annual meeting of the Weed Science Society of America 1979 (Abstract), p 108

Birzer T, Badgery W (2006) Organic wheat farming in Australia: issues farmers face. AFBM 3(2):1-13

Bowman G (ed) (1997) Steel in the field; a farmer's guide to weed management tools, Handbook series book 2. Sustainable Agriculture Network, National Agricultural Library, Beltsville

Boydston RA, Mojtahedi H, Crosslin JM, Brown CR, Anderson T (2008) Effect of hairy nightshade (Solanum sarrachoides) presence on potato nematodes, diseases, and insect pests. Weed Sci 56:151-154

Bridges DC (1992) Crop losses due to weeds in the United States - 1992. Weed Science Society of America, Champaign 
Carson RL (1962) Silent spring. Houghton Mifflin, Boston

Cerdeira AL, Duke SO (2006) The current status and environmental impacts of glyphosateresistant crops: a review. J Environ Qual 35:1633-1658, Reviews and analyses

Conford P (2001) The origins of the organic movement. Floris Books, Edinburgh

Crafts AS (1960) Weed control research: past, present and future. Weeds 8:535-540

Datamonitor (2011) Global: food, beverages and tobacco industry guide

Dill GM, CaJacob CA, Padgette SR (2008) Glyphosate-resistant crops: adoption, use and future considerations. Pest Manage Sci 64:326-331

Dimitri C, Oberholtzer L (2009) Marketing US organic foods: recent trends from farms to consumers, Economic information bulletin number 58. Economic Research Service, United States Department of Agriculture, Washington, DC

Doohan D, Wilson R, Canales E, Parker J (2010) Investigating the human dimension of weed management: new tools of the trade. Weed Sci 58:503-510

Freed VH (1980) Weed science: the emergence of a vital technology. Weed Sci 28:621-625

Gianessi LP, Reigner NP (2007) The value of herbicides in U.S. crop production. Weed Technol 21:559-566

Green JM, Owen MDK (2011) Herbicide-resistant crops: utilities and limitations for herbicideresistant weed management. J Agric Food Chem 59:5819-5829

Grube A, Donaldson D, Kiely T, Wu L (2011) Pesticide industry sales and usage: 2006 and 2007 market estimates. EPA's Biological and Economic Analysis Division, Office of Pesticide Programs, Office of Chemical Safety and Pollution Prevention, U.S. EPA. http://www.epa.gov/ opp00001/pestsales/07pestsales/market_estimates2007.pdf. Accessed 14 July 2011

Gündoğmus E (2006) Energy use on organic farming: a comparative analysis on organic versus conventional apricot production on small holdings in Turkey. Energy Conserv Manage 47:3351-3359

Hartman (2007) The organic marketplace. The Hartman Group, Bellevue

Hartman Group (2010) Reimaging health and wellness: lifestyle and trends report 2010. The Hartman Group Inc. , Bellevue

Heap I (2011) The international survey of herbicide resistant weeds. http://www.weedscience.com. Accessed 14 July 2011

Huber B (2011) The world of organic agriculture: regulations and certification emerging trends 2011. Paper presented at BioFach Congress, Nürnberg, 16-19 February 2011

IFOAM (2005) International Federation of Organic Agricultural Movements, Annual reports 2005-2006, Bonn, Germany

IFOAM (2010) International federation of organic agricultural movements, annual report 2010, Bonn

Kristiansen P, Merfield C (2006) Overview of organic agriculture. In: Kristiansen P, Taji A, Reganold J (eds) Organic agriculture, a global perspective. CSIRO Publishing, Collingwood, pp 1-19

Kristiansen PE, Sindel BM, Jessop RS (2001) Weed control in organic horticultural cropping systems. In: Organic farming workshop, NSW Agriculture Centre for Organic Farming, Bathurst, 5-7 July 2001

Kurstjens DAG (2007) Precise tillage systems for enhanced non-chemical weed management. Soil Tillage Res 97:293-305

Lanini WT (2010) Organic herbicides - do they work? Calif Weed Sci Soc J 6(1):1-3

Letourneau DK, Bothwell SG (2008) Comparison of organic and conventional farms: challenging ecologists to make biodiversity functional. Front Ecol Environ 6:430-438

Mäder P, Fliebach A, Dubois D, Gunst L, Fried P, Niggli U (2002) Soil fertility and biodiversity in organic farming. Science 296:1694-1697

Martinez SW (2007) The U.S. food marketing system: recent developments, 1997-2006, Report number 42. United States Department of Agriculture, Economic Research Service, Washington, DC

McCann E, Sullivan S, Erickson D, De Young R (1997) Environmental awareness, economic orientation, and farming practices: a comparison of organic and conventional farmers. Environ Manage 21:747-758 
Murphy K, Campbell KG, Lyon S, Jones SS (2007) Evidence for varietal adaptation to organic farming systems. Field Crop Res 102:172-177

Murphy KM, Dawson JC, Jones SS (2008) Relationship among phenotypic growth traits, yield and weed suppression in spring wheat landraces and modern cultivars. Field Crops Res 105:107-115

Murray DL (1982) The abolition of El Cortito, the short handled hoe: a case study in social conflict and state policy in California agriculture. Soc Probl 30:26-39

Owen MDK, Zelaya IA (2005) Herbicide-resistant crops and weed resistance to herbicides. Pest Manag Sci 61:301-311

Pimentel D, Hepperly P, Hanson J, Donds D, Seidel R (2005) Environmental, energetic and economic comparisons of organic and conventional farming systems. BioScience 55:573-582

Refsgaard K, Halberg N, Kristensen ES (1998) Energy utilization in crop and diary production in organic and conventional livestock production systems. Agr Syst 57:599-630

Reganold JP, Glover JD, Andrew PK, Hinman HR (2001) Sustainability of three apple production systems. Nature 410:926-930

Sadek NF, Oktarani YP (2009) Consumer knowledge and perception about organic food: a challenge for consumer education and the benefits of going organic. Asian J Food Agro-Ind, Special Issue S363-367

Smil V (2001) Feeding the world: a challenge for the twenty first century. MIT Press, Cambridge, MA

Stolz H, Stolze M, Hamm U, Janssen M, Ruto E (2011) Consumer attitudes towards organic versus conventional food with specific quality attributes. Wagening J Life Sci 58:67-72

Swanton CJ, Harker KN, Anderson RL (1993) Crop losses due to weeds in Canada. Weed Technol 7:537-542

Swinton SM, Buhler DD, Forecella F, Gunsolus JL, King RP (1994) Estimation of crop yield loss due to interference by multiple weed species. Weed Sci 42:103-109

Thompson G (2000) International consumer demand for organic foods. HortTechnology 10:663-674

Timmons FL (1970) A history of weed control in the United States and Canada. Weed Sci 18:294-307

USDA, ERS (2011) Economic Research Service. http://www.ers.usda.gov/data-products/adoptionof-genetically-engineered-crops-in-the-us/recent-trends-in-ge-adoption.aspx\#.Ubi95ticGVI. Accessed 6 June 2013

van der Schans D, Bleeker P (eds) (2006) Practical weed control in arable farming and outdoor vegetable cultivation without chemicals, Publication number 352. Applied Plant Research, Wageningen

Vecchia AV, Gilliom RJ, Sullivan DJ, Lorenz DL, Martin JD (2009) Trends in concentrations and use of agricultural herbicides for Corn Belt Rivers, 1996-2006. Environ Sci Technol 43:9096-9102

Walz E (1999) Final results of the third biennial national organic farmers' survey. Organic Farming Research Foundation, Santa Cruz

Willer H, Kilcher L (eds) (2011) The world of organic agriculture. Statistics and emerging trends 2012. FIBL-IFOAM report. Research Institute of Organic Agriculture (FiBL), Frick and International Federation of Organic Agriculture Movements (IFOAM), Bonn

Willer H, Kilcher L (eds) (2012) The world of organic agriculture. Statistics and emerging trends 2012. FIBL-IFOAM report. Research Institute of Organic Agriculture (FiBL), Frick and International Federation of Organic Agriculture Movements (IFOAM), Bonn

Williams MM II, Boydston RA (2005) Alternative to hand-weeding volunteer potato (Solanum tuberosum) in carrot (Daucus carota). Weed Technol 19:1050-1055

Williams MM II, Ransom CV, Thompson WM (2007) Volunteer potato density influences critical time of weed removal in bulb onion. Weed Technol 21:136-140

Yim FS, Williams MM II, Pataky JK, Davis AS (2009) Principal canopy factors of sweet corn and relationships to competitive ability with wild-proso millet (Panicum miliaceum). Weed Sci 57:296-303

Zimdahl RL (2000) My view. Weed Sci 48:663 
Section II

Principles and Merging of Engineering and Weed Science 


\title{
Chapter 3 \\ Engineering Advancements
}

\author{
John K. Schueller
}

\begin{abstract}
Significant advances have recently occurred, and are continuing to occur, in many of the major engineering fields. Improved motions, structures, and their control are seen with contemporary mechanical engineering technologies. New materials and manufacturing processes make it practical to substantially improve machine performances. Significant advances in computational speed, storage capacities, and networking have made electronic and electrical components, such as machine vision and spectral sensors, more practical and productive. Automation and control technological advances have greatly improved potential system performances. These are among the many engineering advancements which provide techniques to facilitate the technical and economic feasibility of automated weed control.
\end{abstract}

\section{Introduction}

These are exciting times for most engineering fields. Almost all fields are seeing significant advances in research and technology development. Since these advances may impact the technical and economic feasibility of automated weed control, this chapter will review developments in a few of those engineering fields.

\footnotetext{
J.K. Schueller $(\bowtie)$

Center for Manufacturing Innovation, University of Florida,

Gainesville, FL 32611-6300, USA

e-mail: schuejk@ufl.edu
} 